DOI: https://doi.org/10.47405/mjssh.v5i12.621

\begin{tabular}{|c|c|}
\hline 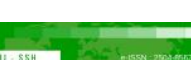 & Malaysian Journal of Social Sciences and Humanities (MJSSH) \\
\hline Malaysian Journal of & Volume 5, Issue 12, December 2020 \\
\hline (MJ-SSH) & e-ISSN : 2504-8562 \\
\hline & $\begin{array}{l}\text { Journal home page: } \\
\text { www.msocialsciences.com }\end{array}$ \\
\hline
\end{tabular}

\title{
Mahathiriskonomism: Memperjelas Peranan Mahathir Mohamad dalam Pengurusan Krisis Ekonomi 1997/98
}

\author{
Md. Shukri Shuib 1, Mohamad Faisol Keling1, Nazariah Osman'1 \\ ${ }^{1}$ School of International Studies (SOIS), College of Law, Government and International Studies, \\ Universiti Utara Malaysia (UUM) \\ Correspondence: Md. Shukri Shuib (wacanashukri@gmail.com)
}

\begin{abstract}
Abstrak
Penulisan ini memfokuskan kepada pengamalan dan pendekatan serta peranan Tun Dr. Mahathir dalam penyelesaian krisis ekonomi 1997/98 dan menumpu kepada pembinaan konsep dinamakan sebagai Mahathiriskonomism. Secara jelas, Tun Dr. Mahathir memainkan peranan dan pembinaan "ism" berasaskan corak pemikiran dan model kepimpinan beliau membantu Malaysia keluar dari kemelut kegawatan krisis ekonomi tersebut tanpa memerlukan bantuan asing yang membelenggu sistem politik dan ekonomi negara. Krisis ekonomi $1997 / 98$ berlaku secara mengejut bagi Malaysia dan menerusi proses pemulihan dilaksanakan kerajaan, ia berjaya dilakukan dengan pantas kerana wujudnya polisi yang dijanakan oleh pengurusan Malaysia sendiri. Mahathirisasi dan elemen pengurusan yang jelas, ditunjangi kekuatan kepimpinan dan sifat keperibadian Tun Dr Mahathir, bersama pasukan pengurusan profesional telah menzahirkan formula Malaysia dalam menangani krisis ekonomi 1997/98. Pendekatan menangani dan memulihkan krisis ekonomi 1997/98 mencetuskan formula dan konsep yang dinamakan sebagai Mahathiriskonomism. Kejatuhan nilai ringgit serta terjadinya krisis kewangan yang memberi impak kepada sektor ekonomi dilihat menjadi satu peristiwa yang merubah pendekatan pengurusan politik dan ekonomi di Malaysia. Krisis ekonomi yang berlaku memberikan impak terhadap Malaysia dengan menjejaskan wawasan serta perancangan pembangunan ekonomi serta menyebabkan gangguan terhadap perancangan untuk mencapai kemajuan yang disasarkan kerajaan. Krisis ekonomi 1997/98 memberikan kesan besar kepada pelbagai sektor terutamanya perbankan, kewangan dan korporat, dan ia juga merunsingkan pihak kerajaan. Proses menangani kegawatan dan melaksanakan pemulihan ekonomi, kerajaan Malaysia yang dipimpin Tun Dr. Mahathir Mohamad menerusi mandat Barisan Nasional berjaya bertindak balas terhadap krisis tersebut dan memperkenalkan cara tersendiri berbanding dasar dan tindakan yang dipraktikkan oleh Thailand dan Indonesia yang menerima bantuan antarabangsa terutamanya IMF. Pengurusan secara profesional menerusi penubuhan Majlis Tindakan Ekonomi Negara (MTEN) pada 7 Januari 1998 bertujuan menguruskan krisis ekonomi dan mengurangkan jurang antara sektor kerajaan dan swasta, dan ini merupakan langkah Mahathirisasi pentadbiran negara semasa krisis. Langkah MTEN yang diperkenalkan oleh kepimpinan Tun Dr. Mahathir Mohamad dengan penghasilan satu kerangka tindakan di namakan sebagai Pelan Pemulihan Ekonomi Negara (PPEN) yang diwujudkan berasaskan orientasi ke arah penstabilan nilai mata wang Ringgit Malaysia di pasaran mata wang antarabangsa telah memberikan kesan positif iaitu ia telah terbukti berjaya mengembalikan keyakinan pelabur terhadap pasaran dan kedudukan ekonomi Malaysia. MTEN menerusi PPEN yang juga berorientasikan untuk mengekalkan kestabilan kewangan, mengukuhkan asas ekonomi dan ekuiti di dapati berjaya dilaksanakan dengan berkesan, dan ia menjayakan aplikasi Mahathiriskonomism dalam pengurusan negara semasa berhadapan krisis politik dan ekonomi.
\end{abstract}

Kata kunci: Mahathiriskonomism, pengurusan krisis, krisis ekonomi 


\title{
.Mahathiriskonomism: Explaining the Role of Mahathir Mohamad in Managing Economic Crisis 1997/98
}

\begin{abstract}
This paper focuses on the practice and approach as well as the role of Tun Dr. Mahathir in resolving the 1997/98 economic crisis and focuses on the construction of a concept called Mahathiriskonomism. Tun Dr. Mahathir played the role and construction of "ism" based on his thought patterns and leadership model to help Malaysia get out of the economic crisis without the need for foreign aid that plagued the country's political and economic system. The 1997/98 economic crisis occurred suddenly for Malaysia and through the recovery process implemented by the government, it was successfully done quickly due to the existence of policies generated by Malaysia's own management. Mahathirization and clear management elements, underpinned by Tun Dr Mahathir's leadership strength and personality, together with his professional management team have unveiled Malaysia's formula in dealing with the 1997/98 economic crisis. The approach to addressing and recovering from the 1997/98 economic crisis triggered a formula and concept called Mahathiriskonomism. The depreciation of the ringgit and the occurrence of the financial crisis that impacted the economic sector are seen as an event that changed the approach of political and economic management in Malaysia. The current economic crisis has an impact on Malaysia by affecting the vision and planning of economic development and causing disruption to planning to achieve the progress targeted by the government. The 1997/98 economic crisis had a major impact on various sectors, especially banking, finance and corporate, and it also worried the government. The process of dealing with the crisis and implementing economic recovery, the Malaysian government led by Tun Dr. Mahathir Mohamad through the Barisan Nasional mandate managed to respond to the crisis and introduced its own way compared to the policies and actions practiced by Thailand and Indonesia that receive international assistance, especially the IMF. Professional management through the establishment of the National Economic Action Council (NEAC) on 7 January 1998 aims to manage the economic crisis and reduce the gap between the government and the private sector, and this is a measure of the Mahathirization of the country's administration during the crisis. MTEN measures introduced by the leadership of Tun Dr. Mahathir Mohamad with the production of a framework called the National Economic Recovery Plan (PPEN) created based on orientation towards the stabilization of the value of the Malaysian Ringgit in the international currency market has given a positive effect that it has proven successful in restoring investor confidence in the market and economic position Malaysia. MTEN through PPEN which is also oriented to maintain financial stability, strengthen economic and equity foundations are found to be successfully implemented effectively, and it succeeds in the application of Mahathiriskonomism in the management of the country during the political and economic crisis.
\end{abstract}

Keywords: Mahathiriskonomism, crisis management, economic crisis

\section{Pengenalan}

Wujud pelbagai kajian mengenai cara Malaysia menghadapi dan menangani krisis ekonomi 1997/98, tetapi ia hanya berkisar soal mekanisme dan cara semata-mata tanpa melibatkan fokus yang khusus mengenai peranan Tun Dr. Mahathir Mohamad sebagai Perdana Menteri yang mengetuai usaha menangani permasalahan yang berlaku. Mengkaji fenomena dan hasil tanpa mempedulikan aktor yang bertanggungjawab dalam memimpin negara berhadapan krisis ekonomi 1997/98 itu adalah satu usaha yang belum lengkap secara akademiknya. Artikel ini melihat dimensi peranan Tun Dr. Mahathir dalam menguruskan negara dari sudut ekonomi dan politik serta mengkaji impak yang diterima hasil dari cara pengurusan beliau semasa krisis tersebut.

Menurut Institute for International Economics, di kalangan empat buah negara Asia yang dilanda krisis ekonomi 1997/98 kajian mendapati bahawa hanya Malaysia sahaja yang mencatatkan sejarah politik ekonomi di mana kerajaan semasa tidak berubah akibat dari kesan peristiwa krisis ekonomi 1997/98 
yang berlaku. Indonesia, Thailand serta Korea Selatan yang juga dikaji dalam kajian institut berkenaan mengalami perubahan rejim pemerintah. Persoalan timbul adalah berkaitan dengan kaedah yang diguna pakai oleh Dr. Mahathir dalam menyelesaikan permasalahan ekonomi dan pergolakan politik secara serentak.

Artikel ini secara khususnya memfokuskan kepada satu hipotesis bahawa peranan yang dilaksanakan oleh Dr. Mahathir Mohamad dalam memimpin Malaysia menghadapi krisis ekonomi yang melanda Asia serta Malaysia pada 1997-1998 adalah begitu signifikan. Kedudukan Dr. Mahathir selaku Perdana Menteri pada ketika itu telah membolehkan beliau bertindak sebagai pemikir dan pencetus kepada solusi atau mekanisme penyelesaian krisis, dan juga mampu menggunakan kedudukan eksekutifnya dalam membentuk pasukan khusus bagi bekerjasama sebagai pemikir (think-tank) serta bertindak balas dengan pembentukan polisi serta tindakan yang bersesuaian.

\section{Peristiwa Krisis Ekonomi 1997/98}

Krisis ekonomi yang melanda Asia termasuk Malaysia pada 1997/98 itu telah mengalihkan pandangan dunia yang turut sama melihat kepada aspek keterlibatan pasaran dan sistem kewangan antarabangsa melibatkan peranan dan keberkesanan dalam menangani krisis ekonomi. Krisis ekonomi yang melanda juga menunjukkan bahawa ia juga disebabkan oleh perubahan dalam arah aliran modal antarabangsa di pasaran modal tempatan sehingga menyebabkan keadaan yang tidak stabil kepada pasaran disebabkan oleh tindakan drastik untuk mengubah haluan pasaran sehingga mewujudkan peralihan dalam keyakinan pasaran (Radelet \& Sachs, 1998).

Krisis ekonomi yang melanda Malaysia dan negara serantau di Asia Timur masih diingati sebagai satu peristiwa terpenting dunia dan negara, ini dapat dilihat dengan jelas menerusi ucapan Y.A.B Perdana Menteri Malaysia, Datuk Sri Mohd Najib Tun Haji Abdul Razak pada 29 November 2014 dengan menyatakan bahawa dalam tahun 1997 ekonomi Malaysia merudum yang mengakibatkan kewangan negara menjadi lemah dan prestasi pembangunan juga merosot (Mingguan Malaysia, 30 November 2014: 7). Kegawatan ekonomi yang melanda Malaysia pada 1997 memberikan beberapa kesan kepada Malaysia dalam aspek ekonomi, sosial dan juga aspek politik.

Sebelum Julai 1997, kedudukan ekonomi negara-negara Asia Timur berkembang pesat dan maju. Kejatuhan nilai mata wang kemudiannya menjadikan kedudukan ekonomi dan kewangan negaranegara terlibat di Asia Timur semakin terjejas. Bath iaitu mata wang Thailand mula mengalami susutan nilai berbanding mata wang asing yang begitu ketara bermula Julai 1997 menjadikan petanda kemerosotan nilai mata wang satu persatu negara-negara Asia Timur. Krisis kewangan yang melanda Asia bermula 14 Mei 1997 apabila berlakunya serangan spekulasi ke atas mata wang Baht dan kegagalan kerajaan Thailand mempertahankan kedudukan nilai mata wang Baht sehingga menyebabkan berlakunya kegagalan beberapa buah syarikat kewangan di negara tersebut pada 23 Mei tahun yang sama (Aaron, 2000: 2).

Menurut Prema-chandra (2010), tekanan ke atas ringgit Malaysia sejak Julai 1997 hingga 7 Januari 1998 sehingga menyusutkan mata wang Malaysia ke paras 50 peratus lebih rendah berbanding dollar Amerika Syarikat. Pada penghujung 1997, nilai saham komposit di BSKL juga telah menurun sebanyak 50 peratus dan menyebabkan pasaran saham Malaysia kehilangan AS $\$ 225$ bilion, sedangkan Malaysia pada tahun 1990 hingga 1995, direkodkan memperoleh US\$26.7 bilion pelaburan langsung asing (FDI) iaitu merangkumi 31.3 peratus dari keseluruhan jumlah FDI yang mengalir ke kalangan negara ASEAN (Dhillon, 2009). Dalam konteks ini, Prema-chandra (2010) telah menegaskan bahawa walaupun Malaysia dilanda kegawatan, pembuat dasar Malaysia dapat menghadapi situasi getir tersebut dengan cara tersendiri berbanding Thailand dan Indonesia yang lebih pantas beralih kepada IMF sebagai alternatif. Ini menunjukkan bahawa kepimpinan dan juga pembuat dasar negara hasil usaha Tun Dr. Mahathir yang paling diingati masyarakat Malaysia dan antarabangsa ialah ketika kejayaan beliau membawa Malaysia keluar dari Krisis Kewangan Asia pada 1997. Ketika krisis itu, Tun Dr. Mahathir telah menolak cadangan dan dana bantuan daripada Dana Kewangan Antarabangsa (IMF) yang beliau sifatkan akan memburukkan lagi krisis itu (pandangan Amin Iskandar di dalam 
Kebebasan bawa erti besar bagi negara, Berita Harian, 23 Ogos 2013). Inilah yang saya rangkumkan sebagai Mahathiriskonomism, iaitu pendekatan khusus secara ilmiah memperincikan impak hasil usaha kerajaan pimpinan Tun Dr. Mahathir dan pemimpin bersamanya dalam memulihkan negara dari kesan buruk krisis ekonomi 1997/98.

\section{Impak krisis ekonomi 1997/98}

Krisis ekonomi yang melanda Asia pada tahun 1997 memberikan impak yang panjang dan hampir meruntuhkan negara-negara ASEAN. Tambahan pula, krisis ekonomi yang melanda bukanlah disebabkan faktor kegagalan kerajaan semata-mata dalam menguruskan sistem kewangan dan ekonomi sesebuah negara. Krisis ekonomi yang melanda pada 1997/98 telah menyebabkan:

i. Timbulnya kesedaran negara-negara terlibat bahawa dalam era globalisasi, kawalan negara ke atas setiap perkara adalah terbatas.

ii. Kesan ketara dari kegawatan ekonomi 1997/98 dapat dilihat secara jelas menerusi beberapa indikator utama, iaitu (Massa, 17-23 Januari 1998): Ringgit menjunam ke paras 4.8800 berbanding AS\$1.00, pasaran saham merudum di bawah paras indeks 500 mata, bank-bank membekukan pinjaman, harga barangan keperluan melambung tinggi dan daya tahan syarikat mula tergugat.

iii. Tekanan memuncak krisis ekonomi yang melanda Malaysia adalah pada Ogos 1998 di mana berlakunya penurunan tertinggi kadar tukaran mata wang bagi ringgit Malaysia. Nilai Ringgit Malaysia (RM) menyusut berbanding dollar Amerika Syarikat sebanyak 50 peratus hingga mencecah kadar tukaran bagi AS\$1 kepada RM4.88 pada 7 Januari, 1997 berbanding pada April 1997 di mana kadar ringgit berbanding dollar Amerika Syarikat hanya pada kadar RM2.42 kepada AS\$1 (Zaherawati et al., 2010).

iv. Tekanan ke atas rizab asing dan juga kenaikan kadar faedah pada paras yang tinggi (Meyer, 1994; Mahani, 2012).

v. Pengaliran keluar modal secara mendadak dengan jumlah yang banyak hingga menyusutkan kedudukan pasaran dan ekonomi serta mengurangkan kadar nilaian bursa saham hingga menyebabkan negara menuju ke arah kemiskinan. Malaysia kehilangan US $\$ 290$ bilion akibat krisis ekonomi 1997/98.

vi. Tempoh waktu antara bulan Julai 1997 hingga pertengahan Januari 1998, nilai saham sebanyak AS $\$ 225$ bilion telah lenyap akibat penyusutan nilai matawang RM (Zaherawati et al., 2010).

vii. Kedudukan bursa saham dan pasaran mata wang Malaysia hampir runtuh akibat krisis yang melanda. Kadar GDP juga menurun dari 7.3 peratus pada 1997 kepada - 7.4 peratus pada 1998, dan ini adalah kadar terburuk sejak kemerdekaan negara pada 1957 (Mahani, 2009; Goh \& Michael, 2010).

viii. BSKL pada 1997 adalah bursa saham ketiga terbesar di rantau Asia Timur selepas Tokyo dan Hong Kong mengalami penurunan mendadak nilaian indeks kompositnya dari 1,077.3 mata pada Jun 1997 ke paras 262.7 mata pada 1 September 1997 (Zaherawati et al., 2010).

ix. Kadar pendapatan per kapita Malaysia telah susut sebanyak 70 peratus, harga nilaian pasaran di bursa saham juga susut sehingga 90 peratus dan menyebabkan banyak perniagaan di Malaysia mengalami gugatan kenaikan kadar hutang yang tinggi (Dhillon, 2009).

x. Gugatan kepada kebanyakan bank dan sektor korporat, dan ini merunsingkan pihak kerajaan (Sulaiman, 2013).

xi. Malaysia secara anggarannya telah kehilangan US\$ 40 bilion dalam aspek kuasa beli, dan ini dinyatakan oleh Dr. Mahathir dalam ucapannya pada 28 November 1997 semasa majlis dialog bersama pemimpin perniagaan di Tokyo, Jepun, dan ini mengakibatkan Malaysia lebih miskin dari sebelum kejatuhan mata wang berlaku dan memberikan kesan kepada rakyat Malaysia secara keseluruhannya (Dhillon, 2009). 
xii. Krisis ekonomi yang berlaku telah menjejaskan wawasan serta perancangan pembangunan ekonomi serta menyebabkan gangguan terhadap perancangan untuk mencapai kemajuan yang disasarkan kerajaan (Mahani, 2002).

xiii. Malaysia mengalami defisit kewangan serta membawa kepada pertumbuhan negara pada kadar negatif (Mohd. Akbal \& Ahmad Zaidi, 2003).

xiv. Impak politik berpunca dari kejatuhan nilai ringgit telah dilihat menjadi antara punca ketegangan politik di antara Tun Dr. Mahathir dan Timbalan Perdana Menteri ketika itu, Datuk Seri Anwar Ibrahim sehingga menyebabkan hubungan politik kedua pemimpin itu semakin renggang ditambah pula oleh tindakan pemecatan Anwar sebagai anggota kabinet dan keahlian UMNO pada 1998 sehingga disabitkan kesalahan penyalahgunaan kuasa oleh Mahkamah kemudiannya. Ketegangan antara dua pemimpin itu telah kemudiannya merebakkan gerakan Reformasi yang dipelopori oleh Datuk Seri Anwar Ibrahim yang dilihat seperti yang turut berlaku di Indonesia, dan gerakan Reformasi tersebut telah kehilangan taringnya setelah keadaan ekonomi Malaysia kembali pulih di bawah pemerintahan Tun Dr. Mahathir Mohamad (Zakaria \& Goshal, 1999).

\section{Konsep Mahathiriskonomism}

Pengistilahan Mahathiriskonomism terbit dari kombinasi nama 'Mahathir', iaitu mantan Perdana Menteri Malaysia keempat, dan digabungkan dengan kata 'risiko ekonomi' bersama 'ism' yang membawa erti pemikiran atau ideologi (Md. Shukri, 2007). Mahathiriskonomism sebagai satu konsep ilmiah telah diketengahkan yang secara umumnya didefinisikan sebagai paradigma atau pemikiran Mahathir berkaitan dalam pengurusan risiko ekonomi yang dihadapi Malaysia semasa pentadbiran beliau sebagai Perdana Menteri Malaysia, terutama ketika melakukan tindakan pemulihan krisis ekonomi 1997/98 (Md.Shukri, Mohamad Faisol \& Mohd Na'eim, 2008). Mahathiriskonomism adalah satu pendekatan mengurus dan menangani risiko ekonomi secara khususnya, dan merupakan pendekatan lebih luas menjangkau pemikiran dan kerangka ideologi konsep politik, ekonomi dan sosial yang sering dinyatakan oleh Md. Shukri (2007) sebagai elemen penting disebut 'trifungsi sejagat'. Pentingnya Mahathiriskonomism ialah ia bercirikan keberanian mengambil risiko dengan konsep pantang berundur.

Mahathiriskonomism dalam tindakan menangani krisis ekonomi 1997/98 semestinya mencirikan pendekatan Mahathirism sebagai teras, iaitu pendekatan berasaskan gaya kepimpinan dan pemikiran Dr. Mahathir yang tersendiri dan bebas dari pengaruh asing. Pandangan ini disesuaikan juga menerusi pengamatan Dr Rais Yatim (2011) yang mengemukakan rumusan berkenaan dengan usaha dan langkah yang dilaksanakan serta dasar termasuk aspek kepimpinan Tun Dr. Mahathir bahawa istilah Mahathirism itu adalah istilah yang boleh digunakan dalam menyatakan segala hal berkaitan Mahathir. "Despite his golden years of nearing 90, Mahathir and indeed Mahathirism - if there be such a term that can be used to describe all things Mahathir" (Rais Yatim, 2011: 237).

Aspek Mahathirism ini secara jelas diperincikan bahawa ia tidak mempunyai batasan dalam waktu dan tindakan, bahkan apa sahaja tindakan Dr. Mahathir dalam pentadbiran dan tingkah laku beliau mampu dikategorikan sebagai Mahathirism (Rais Yatim, 2011).

Mahathir became Mahathirism in many ways. He had his own way of doing things and not many had the dash of mind and psysical vigoutr to achieve what he achieved

(Rais Yatim, 2011: 245)

Terdapat dua faktor utama di kategorikan Dhillon (2008) dalam perkiraan Dr. Mahathir menjana polisi negara, iaitu faktor dalaman (domestic) dan faktor luaran (external), dan ini menjadikan elemen idiosinkritik (idiosyncracies) atau kewibawaan ketokohan Dr. Mahathir itu sendiri memberi kesan 
besar terhadap pembinaan dasar serta polisi yang kukuh bagi Malaysia berhadapan dengan masyarakat Malaysia dan antarabangsa.

Johan (2010: 184) menyatakan bahawa Dr. Mahathir telah membawa elemen dikenali sebagai 'iconoclasm' sebagai elemen peneraju terhadap pembikinan dasar di Malaysia yang berkisar terhadap wawasan yang beliau sendiri janakan. Penggubalan dasar dan pengubah suaian sesuatu polisi adalah menjadi satu keutamaan di era Dr. Mahathir dengan mengambil kira beberapa aspek seperti perubahan era dengan mengambil kira aspek yang tidak dapat dielakkan seperti globalisasi. Sesuatu dasar di Malaysia yang dijanakan juga mengambil kira peranan kepimpinan Dr. Mahathir yang berwatak agresif dalam mencapai matlamat kepentingan nasional (Johan, 2010). Ini disebutkan Dhillon (2008) sebagai Mahathir's idiosyncracies.

Dr. Mahathir dikenali sebagai Perdana Menteri dan pemimpin yang begitu rajin bekerja. Rais Yatim menyatakan hal ini dalam penulisan beliau dengan tulisannya "In Abdullah's psyche is the determination of how to continue a job that has been synonymous with a methodical workaholic, a methaphor which Mahathir has been well known for" (Rais Yatim, 2011: 239). Mahathiriskonomism dengan ciri terasnya iaitu Mahathirism dalam konteks tindakan dan tingkah laku dilaksanakan bagi mendepani krisis ekonomi 1997/98 dapat dilihat menerusi tindakan drastik yang dilaksanakan, antaranya dengan pertentangan politik dan perbezaan pendekatan ekonomi dalam antara Dr. Mahathir dengan Timbalan Perdana Menteri yang juga menteri kewangan ketika itu Datuk Seri Anwar Ibrahim, dan Dr. Mahathir dengan sifat Mahathirism tersendiri dengan gaya dan pendekatannya mengambil tindakan drastik bukan sahaja melakukan perubahan dasar, tetapi bertindak menyingkirkan timbalan beliau sendiri, dan kemudian-nya bertindak dengan gaya tersendiri bagi menyelesaikan krisis ekonomi yang dihadapi negara. Rais Yatim (2011) menyatakan bahawa:

In 1997 in the midst of the world's worst financial crisis Mahathir, contrary to the stand of his deputy, Anwar Ibrahim, introduced a sea of change in Malaysia's economic and fiscal basics. He caused to be mopped the Malaysian ringgit overseas so as rendering it to be non legal tender. The ringgit poured back into the country. As incentive, he even chose not to tax anyone who brought back huge sums of money into the country. He then disallowed capital outflow. (Rais Yatim, 2011: 245).

Menurut Md. Shukri (2008), menerusi model Mahathiriskonomism wujud keberkesanan yang efektif dalam pengurusan stres ekonomi dan ini dibuktikan dengan keupayaan aplikasi model Mahathiriskonomism di Malaysia. Menerusi aplikasi Mahathiriskonomism, ia telah melonjakkan pertumbuhan Malaysia dari -7.5 peratus pada 1997 dengan pertumbuhan sebanyak 13.3 peratus kepada 5.8 peratus pada 1999. Pertumbuhan itu mengulangi kejayaan pimpinan Tun Dr. Mahathir semasa menangani krisis ekonomi 1985 dengan kadar pertumbuhan mencecah -1 peratus kepada 1.2 peratus (1986) dan 8.7 peratus (1988).

Krisis ekonomi 1997/98 berlaku secara mengejut bagi Malaysia dan menerusi proses pemulihan dilaksanakan kerajaan, ia berjaya dilakukan dengan pantas kerana wujudnya polisi yang dijanakan oleh pengurusan Malaysia sendiri (Mahani, 2002). Dr. Mahathir berjaya memahami situasi yang berlaku dan cepat bertindak ke arah penyelesaian krisis. Malaysia di bawah pentadbiran diketuai Dr. Mahathir berjaya menyediakan negara dengan kaedah tersendiri penyelesaian krisis ekonomi tanpa perlu mengikut terma dan syarat yang ditawarkan IMF melalui kaedah pemulihan ekonomi yang disediakan (Mahani, 2002:253), ini menunjukkan dengan jelas dan tepat bahawa pendekatan Mahathiriskonomism adalah satu kaedah unik dalam membantu pemulihan negara dari krisis ekonomi yang melanda.

Dapat dikenal pasti bahawa wujud beberapa ciri asas kepada pemikiran Mahathir dalam penentuan sesuatu keputusan, menurut Adnan (2003) asas pemikiran Mahathir tersebut adalah meliputi elemen pemikiran yang merangkumi aspek-aspek berikut:

i. Kembali kepada asas, iaitu menyoal fundamental dan mencari penjelasan paling mudah kepada sesuatu masalah. 
ii. Menongkah arus, suatu berbekalkan kefahaman kuat tentang fundamental, beliau berani mengutarakan idea yang jelas berbeza dari sedia ada atau tidak bersifat konvensional semasa.

iii. Membuat keputusan betul, yakni sifat ini terterap sebagai sifat usahawan yang berjaya dan setiap keputusan yang dijanakan adalah juga berpaksikan kepada tidak hanya bersifat betul atau terbaik tetapi ia lebih menekankan kepada elemen bahawa keputusan yang dilakukan adalah perlu direalisasikan sehingga membuahkan hasil.

Dr. Mahathir berjaya memahami situasi yang berlaku dan cepat bertindak ke arah penyelesaian krisis. Malaysia di bawah pentadbiran diketuai Dr. Mahathir berjaya menyediakan negara dengan kaedah tersendiri penyelesaian krisis ekonomi tanpa perlu mengikut terma dan syarat yang ditawarkan IMF melalui kaedah pemulihan ekonomi yang disediakan. Dr. Mahathir sanggup mengadakan penerangan awam ke serata Malaysia sepanjang Julai 1998 bagi menerangkan situasi yang berlaku akibat krisis ekonomi yang melanda negara kepada pemimpin dan rakyat untuk difahami. Selain dari perhimpunan rakyat, Dr. Mahathir juga bertemu dengan kebanyakan pemimpin, menjelajah serata bandar sebelum langkah seterusnya dilakukan bagi menangani krisis ekonomi terutamanya apabila kawalan modal dan mata wang hendak dilaksanakan kerajaan (Mahani, 2002:253).

Menurut Jomo (2007; Johan, 2010:299), pentadbiran Tun Dr. Mahathir sebagai Perdana Menteri Malaysia pada tahun 1997 hingga tahun 2003 disebutkan sebagai fasa "pengurusan krisis" (crisis management, 1997-2003). Krisis ekonomi 1997/98 memberikan kesan pengucapan ke atas agenda mentransformasikan politik ekonomi Malaysia, dan ianya juga memberikan kesan yang sama ke atas kebanyakan negara Asia Tenggara (Johan, 2010:300). Jomo (2007) membahagikan era pentadbiran Tun Dr. Mahathir kepada tiga fasa, iaitu:

i. Fasa pembangunan industri berat (heavy industrialization) (1981-1985).

ii. Fasa liberalisasi ekonomi (1986-1997)

iii. Fasa pengurusan krisis (crisis management) (1997-2003).

Selain itu, Mahani (2002:253-255) menggariskan beberapa faktor penting dalam aspek kepimpinan yang membawa kejayaan Dr. Mahathir sebagai pengurus yang baik dalam menyelesaikan krisis ekonomi 1997/98. Antara faktor-faktor itu ialah:

i. Legitimasi

ii. Kemahiran berfikir secara strategic (strategic thinking skill)

iii. Visi dan misi (vision and mission)

iv. Rekod pencapaian yang terbukti (proven track record)

v. Pengorganisasian mekanisme pengurusan krisis (Organisation of Crisis Response Machinery)

Langkah Mahathiriskonomisme dalam penyelesaian krisis ekonomi 1997/98 dapat dilihat secara ketara menerusi langkah-langkah berikut:

i. Mahathir mengambil alih posisi sebagai Menteri Kewangan dan mengawal keseluruhan fungsi penting sistem ekonomi dan kewangan negara. Konsep perdana menteri sebagai menteri kewangan mula menjadi tradisi dalam sistem eksekutif di Malaysia sejak 1998 hingga kini.

ii. Pemusatan proses pembuatan keputusan secara kolektif dengan penubuhan sebuah majlis tindakan khusus iaitu Majlis Tindakan Ekonomi Negara (MTEN) bersama kewujudan Pelan Pemulihan Ekonomi Negara (PPEN). Ini adalah langkah penginstitusian yang menguasai langkah ekonomi yang diambil kerajaan.

iii. Kawalan modal dan penetapan kadar tukaran mata wang asing berbanding RM adalah satu senjata utama yang berjaya di formulasikan dengan berkesan. Langkah ini seolah-olah menyimpan deposit asing untuk jangka masa tertentu dan mengelakkan pengunduran dana asing secara mendadak dari pasaran kewangan Malaysia. Ia membantu per unjuran wang dan dana sedia ada dalam pasaran oleh kerajaan.

iv. Penggabungan bank serta kewujudan institusi insurans pendeposit mewujudkan keyakinan pasaran awam kepada institusi kewangan semasa. 
v. Kewujudan Dana Harta dan Dana Modal sebagai langkah pro aktif melindungi modal dan harta peniaga di Malaysia dari jatuh ke tangan asing telah memberi kesan nasionalisme ekonomi yang positif.

Schuman (2009) menegaskan bahawa pendekatan Dr. Mahathir banyak dipengaruhi oleh pendekatan dan pengamalan pembangunan yang diamalkan oleh Jepun dan Korea Selatan. Menerusi pendekatan yang dikenali sebagai 'model asia' yang dipelopori Jepun telah juga diadaptasi oleh Dr. Mahathir dalam konteks Malaysia bagi memberikan satu model yang menggambarkan hubungan saling bergantungan antara kerajaan dan perniagaan dalam sistem ekonomi negara dengan istilah "Malaysia Inc" atau "Pensyarikatan Malaysia". Pendekatan yang dilaksanakan Malaysia pada pentadbiran Dr. Mahathir secara jelas adalah berkaitan rapat dengan personaliti Dr. Mahathir sendiri (Schuman, 2009). Secara kesimpulannya, model pembangunan Malaysia adalah berasaskan kepada kekuatan Dr. Mahathir dalam memberikan inspirasi dan hala tuju hingga membolehkan beberapa model dan dasar pembangunan Malaysia diperkenalkan pada era pentadbiran beliau. Schuman (2009) menyifatkan Dr. Mahathir dalam penulisan beliau sebagai 'leaders of Miracle' (pemimpin ajaib) dan menyatakan Dr. Mahathir bukan sahaja seorang nasionalis tetapi juga merupakan aktivis Melayu. Hujahan Schuman (2009) itu memperjelaskan bahawa Dr. Mahathir ini seorang yang berprinsip yang kuat berpegang dengan usaha kuat bagi membawa Malaysia berubah kepada sebuah negara berdaya saing yang maju. Dr. Mahathir berjaya membawa Malaysia sebagai sebuah negara Islam di dunia yang berbeza dengan lain-lain negara Islam di mana Malaysia sebagai sebuah negara yang didominasi secara majoritinya oleh umat Islam tetapi memiliki keupayaan ekonomi yang mapan serta mampu mendepani kemajuan dan diiktiraf peringkat antarabangsa (Schuman, 2009).

Menurut Dhillon (2009: 95), kejayaan Malaysia yang diistilahkan sebagai 'Malaysian miracle' dicapai menerusi 'formula Mahathir' yang dilaksanakan menerusi pelbagai dimensi usaha termasuklah dalam aspek memodenkan negara, pengindustrian, keterbukaan atau liberalisasi serta penswastaan dalam aspek pembangunan dan pertumbuhan ekonomi negara. Bahkan Dhillon (2009) turut menegaskan bahawa aspek polisi serta dasar yang dijalankan Malaysia pada era kepimpinan Dr. Mahathir juga banyak tertumpu kepada penumpuan usaha kepada aspek pembangunan.

Oleh itu, konsep dan pendekatan Mahathiriskonomism ini merupakan satu kerangka yang universal dan mampu diaplikasikan di dalam semua lapangan pendekatan pembangunan bukan sahaja di Malaysia, namun ia mampu memberikan model kepada negara-negara ekonomi sedang membangun termasuk juga kepada dunia maju sendiri.

\section{Pendekatan Mahathiriskonomism semasa berhadapan krisis ekonomi}

\section{Pengukuhan proses Mahathirisasi dalam kepimpinan Malaysia}

Semasa berlaku krisis ekonomi, Malaysia memerlukan kepimpinan yang berani dan Dr. Mahathir telah berjaya melakukan yang terbaik dalam kepimpinannya mengharungi krisis yang melanda. Ini menunjukkan peranan Dr. Mahathir sebagai pemimpin yang tepat semasa Malaysia dilanda krisis menjadi satu angkubah penting dalam penyelesaian krisis (Mahani, 2002). Menurut Ahmad Faiz Abdul Hamid (Johan, 2010), Dr. Mahathir lebih mengamalkan proses pembuatan keputusan yang dinamakan "top-down process", di mana kehadiran kepimpinan dalam proses membuat keputusan itu dapat dirasai kewujudannya secara lebih dominan. Secara asasnya, pembinaan dasar di Malaysia ditentukan oleh beberapa angkubah dan angkubah ini juga kekal sama pengaruhnya di era pentadbiran Dr. Mahathir sebagai Perdana Menteri, angkubah itu ialah meliputi aspek sejarah, luaran, dalaman dan juga faktor idiosinkratik atau wibawa ketokohan (idiosyncratic) (Johan, 2010).

Mana-mana negara yang sedang berhadapan dengan pergolakan termasuk dalam soal kemelut ekonomi haruslah mempunyai pemimpin yang dinamik bagi memulihkan keadaan dan membina semula keyakinan serta memimpin ke arah hala tuju penyelesaian (Mahani, 2002). Mahani (2002) menyatakan bahawa semasa berlaku krisis ekonomi, Malaysia memerlukan kepimpinan yang berani dan Dr. Mahathir telah berjaya melakukan yang terbaik dalam kepimpinannya mengharungi krisis yang 
melanda. Ini menunjukkan peranan Dr. Mahathir sebagai pemimpin yang tepat semasa Malaysia dilanda krisis menjadi satu angkubah penting dalam penyelesaian krisis.

Pada era Dr. Mahathir sebagai perdana menteri, gaya pentadbiran beliau secara ilmiahnya dikategorikan sebagai authoritarian capitalist political regime bagi memenuhi authoritarian capitalist political regime dan ia dilakukan adalah bagi disesuaikan dengan cabaran baru pasca perang dingin, pendekatan Dr. Mahathir digambarkan seeking its "neo-mercantilist" niche in the rapidly changing international division of labour of a post- Cold War regional and global political realignment (Johan, 2010: 185). Polisi atau dasar sesebuah pentadbiran negara perlulah bersesuai dengan era pelaksanaannya, berasaskan permintaan dan juga diperlukan oleh masyarakat (Mahani, 2002).

Mahathiriskonomism juga berasaskan kepada tindakan Mahathirisasi. Mahathirisasi kepimpinan secara jelas adalah tindak balas Dr. Mahathir dalam mendepani krisis ekonomi 1997/98 yang melanda negara ketika itu adalah mengambil kira aspek ekonomi dan politik secara bersama. Aspek ekonomi dan politik tidak dapat dipisahkan. Ini menunjukkan dengan jelas bahawa peranan Dr. Mahathir dalam pengurusan situasi semasa krisis ekonomi sedang melanda Malaysia mengambil berat terhadap keseimbangan antara impak politik dan ekonomi dalam proses mengurus serta melaksanakan kerangka tindakan yang bersesuaian dengan situasi Malaysia.

Menurut Sivamurugan (2005: 116), kesan krisis ekonomi yang berlaku telah menyebabkan berlakunya ketegangan politik. Kesan kegawatan ekonomi turut sama berlaku serentak dengan pemecatan Anwar Ibrahim telah juga memberikan kesan kepada hubungan antarabangsa, termasuk mengeruhkan hubungan baik Malaysia-Washington pada era pentadbiran George W. Bush. Ini sekali gus menunjukkan secara khusus bahawa peristiwa krisis ekonomi yang berlaku pada 1997/98 memberikan impak hubungan antarabangsa kepada Malaysia (Johan, 2010: 335). Ia memberikan kesan ketara dan merubah aspek suasana kepimpinan politik dalam negara hingga membawa kepada pemecatan Anwar Ibrahim yang pada ketika itu Timbalan Perdana Menteri yang juga merangkap Menteri Kewangan, di mana pemecatan Anwar itu turut melibatkan jawatan sebagai Timbalan Presiden UMNO yang disandangnya, selain tindakan pelucutan keahlian beliau dari Pertubuhan Kebangsaan Melayu Bersatu (UMNO) yang dilakukan atas keputusan yang dicapai dalam mesyuarat Majlis Tertinggi UMNO pada September 1998 (Sivamurugan, 2005), ini kerana Anwar kelihatan bersedia untuk memberikan kerjasama dan menyokong dasar IMF yang cuba diperkenalkan di Malaysia dan rantau Asia Tenggara ini (Sivamurugan, 2005).

Mahathirisasi pada era menghadapi krisis ekonomi 1997/98 dapat juga diamati menerusi pengamatan Jomo (2004) bahawa sejak Julai 1997, terdapat beberapa fasa dan keadaan yang rumit dalam aspek perbincangan mengenai krisis ekonomi yang melanda Malaysia. Pada fasa awal krisis, berlaku perubahan perhubungan antara aspek 'high politics' dengan aspek pengurusan krisis. Bahkan menerusi pendekatan yang dilaksanakan semasa menangani krisis ekonomi sejak Julai 1997 hingga September 1998, kelihatan jelas ketidakserasian di antara Mahathir selaku Perdana Menteri dan Anwar yang merupakan Timbalan Perdana Menteri merangkap Menteri Kewangan pada ketika itu. Umum mengetahui bahawa berlakunya pendekatan berbeza dalam soal dasar ekonomi dalam usaha menangani krisis ekonomi yang melanda (Jomo, 2004). Menurut Jomo (2004), krisis politik yang melanda Malaysia sejak September 1998 adalah berkaitan langsung dengan kesan krisis ekonomi 1997-98 yang melanda Malaysia. Ini bermakna krisis ekonomi 1997-98 juga membawa dimensi krisis politik di antara tokoh politik dalam kerajaan, dan ini juga menarik perhatian Zaherawati et. all (2010) yang menyimpulkan pandangan bahawa di sebalik berlakunya krisis ekonomi ini, maka pertelingkahan antara Dr. Mahathir dan Anwar menyebabkan berlakunya ketidakstabilan dalam arena politik pada kala negara sedang berhadapan krisis ekonomi ini. Secara signifikannya, perhubungan elemen ekonomi dan politik jelas memberikan satu huraian yang jelas betapa unsur itu memberikan signifikasi utama dalam penerusan aspek kepimpinan dan keutuhan legasi pemerintahan. Hubungan ekonomi-politik mempunyai hubungan resiprokal dalam membantu memberikan kekuatan kepada aspek kepimpinan dan ianya merupakan elemen yang sangat penting bagi membantu dalam kepimpinan terus menjana sokongan dan meneruskan legitimasi sesuatu rejim pemerintahan negara. 
Menurut Hwang (2003: 280), telah berlaku pertentangan pandangan antara Dr. Mahathir dan Anwar Ibrahim dalam menangani krisis ekonomi yang melanda Malaysia. Dr. Mahathir lebih menyalahkan faktor luaran sebagai penyebab kepada berlakunya gugatan ekonomi menerusi kejatuhan nilai RM di pasaran mata wang antarabangsa, serta cenderung kepada usaha melonggarkan polisi mata wang dan fiskal negara bertujuan bagi menggalakkan serta meningkatkan kadar pertumbuhan serta mengelakkan kedudukan ekonomi dari terjebak ke kancah kemelesetan. Barry (2009) melihat tindakan pemecatan Anwar dari kerajaan sehari selepas Dr. Mahathir melaksanakan kawalan modal dalam menangani krisis ekonomi yang berlaku dilihat signifikan bahawa wujud pertentangan pendapat antara mereka berdua. Sebaliknya, Anwar yang merupakan Timbalan Perdana Menteri merangkap menteri kewangan Malaysia pada ketika itu pula lebih berfokus kepada masalah dalaman yang dihadapi sebagai punca berlakunya krisis ekonomi yang melanda negara. Anwar juga cenderung kepada langkah mengetatkan kawalan kepada polisi mata wang dan mengambil langkah yang dicadangkan oleh IMF (Hwang, 2003). Pada ketika itu juga, Anwar dan para penyokongnya mengkritik pembangunan yang dilaksanakan kerajaan yang dikenali dengan istilah 'projek mega' dan mengkritik gaya pengurusan Dr. Mahathir pada ketika itu sebagai kurang telus dalam soal penswastaan perniagaan milik negara, dan wujud 'patronage' yang dikatakan Anwar sebagai memenuhi kehendak Dr. Mahathir (Hwang, 2003), media asing melihat bahawa pertentangan dalam soal menguruskan polisi ekonomi dalam mengatasi krisis ekonomi 1997/98 tersebut adalah penyebab utama berlakunya pertentangan antara kedua pemimpin kerajaan pada ketika itu iaitu antara Dr. Mahathir dan Anwar. Ia ketara berlangsung sejak pertengahan tahun 1997 hinggalah membawa kepada pemecatan Anwar dari kerajaan dan UMNO pada September 1998 (Hwang, 2003: 281). Langkah diambil Dr. Mahathir ini seolah-olah satu usaha menunjukkan bahawa Anwarisasi ke atas Malaysia berjaya di atasi dengan memperlihatkan agenda Mahathirisasi sebagai satu kaedah kepada Mahathiriskonomism dalam mengatasi krisis ekonomi ketika itu.

Secara rumusannya, Sivamurugan (2005) jelas menegaskan bahawa kedua-dua elemen politik dan ekonomi adalah unsur yang saling perlu-memerlukan antara satu sama lain dalam membina jaminan kukuh terhadap kesinambungan kuasa. Pengukuhan kuasa dalam konteks menghadapi pembinaan pentadbiran dan pengurusan krisis yang berkesan, maka proses Mahathirisasi politik-ekonomi yang dilakukan oleh Dr. Mahathir jelas menjadikan ia sebagai elemen Mahathiriskonomism.

\section{Memantapkan pendekatan "self-suffience" dan nasionalisme dalam aplikasi pertahanan menyeluruh}

Dalam konteks Malaysia, sejak 1970, kerajaan telah mengambil pendekatan self-suffience sebagai sebahagian daripada langkah negara menghadapi sebarang perubahan di peringkat global. Pengamalan pendekatan self-suffience dilakukan Malaysia membabitkan dalam hal dasar industri dan proses industrialisasi negara serta juga dalam mengadakan kerjasama di peringkat antarabangsa dalam mempertahankan kepentingan nasional. Kenyataan mengenai tindakan kerajaan Malaysia mengutamakan dasar nasional dan antarabangsa dengan disesuaikan menerusi adaptasi realisme dan self-suffience dinyatakan pertama kali secara langsung pada persidangan tahunan IMF dan IBRD oleh Menteri Kewangan pada ketika itu (Johan, 2010).

Aspek pembangunan di Malaysia dilihat sebagai sebahagian elemen dalam aspek keselamatan menyeluruh (comprehensive security) negara dan menjadi tema utama kepada kerajaan, dan ianya telah dinyatakan oleh Datuk Musa Hitam pada 1984 (Mohd Yusof, 1990). Tun Dr. Mahathir berpendirian bahawa di Malaysia eleman ketahanan negara dilihat bukan semata berasaskan kepada kekuatan ketenteraan. Bagi Dr. Mahathir, elemen awal pertahanan ialah ketahanan nasional (national resilience) (Mohd Yusof, 1990). Pernyataan Dr. Mahathir tersebut dapat dilihat jelas menerusi ucapannya pada majlis pembukaan Global Community Forum di Kuala Lumpur pada Disember 1984 yang menyatakan:

We in Malaysia believe that the first line of defence of any country is not its military capability. The first line of defence is its national resilience and in shaping a strategic enviroment where threats are minimised (Mohd Yusof, 1990; The Star, 4 Disember 1984).

Nordin Sophiee menyatakan bahawa di Malaysia, elemen memperkasakan perpaduan nasional, keharmonian kaum, keselamatan sosial, kestabilan politik beserta dengan pertumbuhan ekonomi dilihat 
sebagai elemen keselamatan negara (Mohd Yusof, 1990). Untuk itu, usaha mempertingkatkan tahap pembangunan dan sekali gus memberikan rakyat peluang menikmati tahap kehidupan (living standards) yang lebih baik diutamakan kepimpinan Malaysia sebagai salah satu strategi keselamatan negara (Mohd Yusof, 1990; The Star, 14 Disember 1984). Strategi kepimpinan Malaysia pada era Dr. Mahathir yang mementingkan aspek pengurusan negara semasa krisis tanpa perlu campur tangan asing adalah antara salah satu ciri utama yang dipentingkan.

Langkah dan tindakan yang dilaksanakan oleh Dr. Mahathir dan pentadbiran yang diketuai beliau semasa menghadapi ancaman kesan dari krisis ekonomi yang melanda dibuat juga berasaskan kepada beberapa aspek penting, seperti yang dinyatakan Sivamurugan (2005), eksperimen dasar yang bercorakkan IMF telah menyebabkan kedudukan atau kondisi ekonomi domestik di Malaysia dilihat tidak berganjak dan ia juga tidak membantu dalam mendapatkan serta memulihkan sokongan pasaran dalam kerangka mengatasi masalah yang menimpa Malaysia ketika krisis ekonomi 1997/98 tersebut. Untuk itu, pada ketika merangka pelan tindakan mengatasi krisis ekonomi yang melanda ketika itu, maka elemen nasionalisme dan sikap anti-Amerika Syarikat termasuk IMF menyebabkan Dr. Mahathir memikirkan alternatif yang perlu dilaksanakan bersesuaian dengan keadaan semasa negara. Ini sekaligus mengesahkan bahawa secara nyata, elemen pengurusan semasa menghadapi krisis ekonomi yang melanda Malaysia dirangka sendiri oleh idea dan kecekapan pemikiran serta pengurusan cara Malaysia tanpa perlu terjebak dengan belenggu syarat ketat oleh pihak IMF dan institusi Barat. Elemen sifat kebangsaan atau cintakan negara yang juga disebutkan sebagai nasionalis jelas menjadi elemen mempengaruhi proses pembuatan keputusan di dalam konteks penyelesaian krisis ekonomi dan pengurusan ekonomi serta politik di Malaysia ketika itu oleh Dr. Mahathir.

Dalam menghadapi kemelut ekonomi yang tidak menentu ketika itu, Dr. Mahathir pada 9 Januari 1998 mengetengahkan beberapa kaedah yang difikirkan perlu bagi rakyat bersama kerajaan laksanakan bagi membantu menghadapi krisis ekonomi yang melanda negara. Kaedah ini menunjukkan komitmen kebangsaan yang jitu secara khusus tersirat dalam cara pengurusan Dr Mahathir. Langkah yang dicadangkan ini lebih kepada aplikasi pendidikan nasionalisme semasa krisis kepada rakyat untuk diterapkan dalam kehidupan. Kaedah-kaedah itu ialah (Massa, 17-23 Januari 1998):

i. Meyakini ringgit dan pasaran saham negara

ii. Menabung lebih banyak

iii. Mengurangkan bahan import

iv. Pendeposit harus tidak bimbang

v. Membeli saham

vi. Memahami situasi ekonomi

vii. Suri rumah perlu berdisiplin

viii. Memiliki wang perlu dibelanjakan, tetapi perlu bijak

ix. Jual gelang tangan kalau tak perlu

x. Jangan simpan duit bawah bantal

xi. Tak salah makan marjerin ganti mentega

xii. Jual harta di luar negara

xiii. Sanggup terima pendapatan lebih rendah

xiv. Kukuh semangat hadapi cabaran

xv. Didik anak belanja berhemat

Semangat nasionalisme atau betapa jelas sikap kebangsaan Dr. Mahathir dapat diperlihatkan dengan pernyataan beliau bahawa Malaysia berjaya keluar daripada kolonialisme baru yang beliau dapati dilakukan menerusi manipulasi pasaran kewangan yang membawa kesan buruk kepada Malaysia. Usaha dilaksanakan Dr. Mahathir jelas berjaya mengekalkan autonomi tersendiri bagi Malaysia dalam pasaran ekonomi antarabangsa ketika menghadapi krisis yang berlaku (Sivamurugan, 2005). Pencapaian Dr. Mahathir dalam menguruskan krisis ekonomi 1997/98 yang melanda Malaysia juga mendapat pengiktirafan global dan dibanggakan sebagai satu pencapaian orang Muslim sedunia (Sivamurugan, 2005), dan organisasi kewangan Islam Amerika telah memberikan satu anugerah 'pencapaian seumur hidup' kepada Dr. Mahathir atas kejayaan mengatasi krisis ekonomi yang 
melanda, serta melambangkan supaya corak kepimpinan sebegini menjadi contoh kepada kepimpinan lain.

\section{Memperkukuhkan model pertumbuhan ekonomi}

Model pembangunan dan pengurusan yang kukuh membantu sesebuah negara maju dan terpimpin pelaksanaan polisi serta kemajuannya. Sejak 1993-1997, Malaysia telah merekodkan pertumbuhan ekonomi yang tinggi, dan berjaya mengekalkan dasar fiskal negara di tahap lebihan (surplus) (Ariff, 2009; Goh \& Michael, 2010). Apabila sahaja terjadinya krisis ekonomi 1997/98, maka Malaysia mula mengalami bajet defisit yang bertujuan bagi merangsang kedudukan ekonomi supaya berkembang, dan ini berterusan sehingga kini (Goh \& Michael, 2010). Ini menunjukkan bahawa kesan dari kejadian krisis ekonomi 1997/98 memberikan impak ketara dari segi perancangan pembangunan dan mempengaruhi bajet kerajaan sehingga wujud keperluan mengadakan bajet defisit bagi tujuan pemulihan dan merancakkan pertumbuhan ekonomi negara. Walaupun negara berhadapan dengan bajet defisit, namun, ianya tidak melibatkan aspek seperti pinjaman asing yang banyak dan juga tidak sama sekali melibatkan cetakan wang bagi pembiayaan kerajaan, tetapi ia dilaksanakan secara berhemah menerusi pinjaman bersumberkan dana dalam negara kerana kedudukan tahap simpanan wang bagi penduduk di Malaysia berada pada kedudukan yang tinggi, ia membolehkan institusi yang wujud di Malaysia sendiri berupaya memberikan pinjaman kepada kerajaan dalam bentuk sekuriti yang terjamin (Goh \& Michael, 2010)

Ramon (1997: 123) secara jelas mengaitkan faktor kepimpinan yang bersesuaian (leadership ideals) dengan keupayaan untuk membantu Malaysia dalam menghadapi krisis ekonomi adalah merupakan satu faktor terpenting. Di Malaysia, dari sudut politiknya, Malaysia bertuah kerana mempunyai pemimpin yang berdaya saing serta sesuai dengan zaman. Dari sudut perniagaan, kepimpinan negara dilihat sebagai tokoh yang mampu membawa kesesuaian dan penerimaan baik dari kalangan kakitangan awam serta juga para ahli perniagaan, dan ini menunjukkan bahawa setiap perdana menteri Malaysia memiliki daya kepimpinan yang sesuai dengan situasi negara (Navaratnam, 1997). Navaratnam (1997) juga kerap kali menyebutkan betapa bertuahnya Malaysia kerana dalam setiap pengurusan ekonomi negara, peranan Perdana Menteri dan Menteri Kewangan dilihat menjadi faktor peneraju utama dalam memastikan keseimbangan fiskal yang kukuh dan disiplin pengurusan kewangan negara tercapai dengan baik.

\section{Aplikasi Mahathiriskonomism Menerusi Majlis Tindakan Ekonomi Negara (MTEN)}

Dalam konteks Malaysia wujud perkaitan yang rapat antara kerangka politik Malaysia dengan pengurusan krisis kewangan yang berlaku. Kekuatan kepimpinan politik Malaysia menjadi asas kukuh kepada kejayaan mengurus krisis ekonomi dengan lebih mantap, dan situasi ini tidak dimiliki Filipina dan juga Thailand. Kedudukan institusi di Malaysia termasuk dalam aspek kestabilan kepimpinan politik menambahkan keyakinan pengurusan krisis ekonomi walaupun polisi yang dilaksanakan itu bersifat fleksibel tetapi ia tetap memiliki tindakan yang kukuh dengan hala tuju yang jelas. Menurut MacIntyre (2001), dalam penulisannya bertajuk institutions and investors: the politics of economic crisis in southeast asia menyatakan bahawa politik mempunyai perkaitan dengan krisis ekonomi, dan teori institutional dikemukakan sebagai asas, dan di Malaysia menerusi Mahathiriskonomism yang mengambil langkah Mahathirisasikan pengurusan kerajaan dan juga pendekatan semasa pengurusan krisis ekonomi, ia menunjukkan dengan jelas bahawa kepimpinan dan juga keterlibatan politik dalam menangani krisis ekonomi adalah jelas. Ciri yang dinyatakan MacIntyre (2001) iaitu dengan tidak berlaku penarikan semula polisi kerajaan telah meyakinkan pelabur dan peniaga di pasaran. Ini menunjukkan betapa pengukuhan institusi yang jelas berkait antara elemen politik dan ekonomi sebagai mekanisme pengurusan dan badan bertindak adalah penting bagi menghadapi krisis ekonomi yang dilalui sesebuah negara. Kecekapan kepimpinan dan pengurusan negara dikendalikan ahli politik kerajaan adalah elemen penting. Pemantapan institusi juga satu kaedah diguna pakai Dr. Mahathir semasa krisis ekonomi. Langkah pentadbiran pengurusan ekonomi era Dr. Mahathir menangani kegawatan ekonomi 1997/98 dengan mengadakan satu badan penasihat dan tindakan pengurusan ekonomi negara. Penubuhan Majlis Tindakan Ekonomi Negara (MTEN) dijadikan platform sebagai badan perunding kepada Jemaah Menteri (cabinet) bagi tujuan menyediakan kerangka pengurusan 
ekonomi negara semasa gawat. Justeru, agenda Mahathiriskonomism juga telah bertindak secara kolektif dan bukan bersifat individualis semata, tetapi bersifat kolektivisme.

Secara tersiratnya, bagi saya, MTEN ditubuhkan sebagai satu sumber kuasa yang luas dalam mendapatkan maklum balas dari segenap kementerian dan agensi, menyediakan daya pemikiran, membina polisi serta mengarahkan tindakan dan menilai kesan tindakan kepada kedudukan semasa ekonomi negara. Ia adalah satu Majlis yang menjadi "kabinet khas" yang bukan sahaja dianggotai oleh menteri yang terpilih, tetapi melibatkan juga para birokrat terpenting negara bersama tokoh-tokoh penting di sektor korporat dan para ilmuwan yang arif. MTEN ini secara jelas dikawal penuh oleh Perdana Menteri selaku Pengerusi Majlis iaitu Dr. Mahathir Mohamad. Jadi, ia adalah satu "punca kuasa' yang khas dijanakan Dr. Mahathir sebagai mekanisme profesional dalam "mencipta" formula khusus bagi memulihkan kedudukan ekonomi negara semasa krisis ekonomi 1997/98 melanda.

Dalam proses menangani kegawatan ekonomi dan melaksanakan pemulihan ekonomi, kerajaan semasa pemerintahan Tun Dr. Mahathir Mohamad telah berjaya bertindak balas terhadap krisis tersebut dan memperkenalkan sistem yang berlawanan seperti yang dipraktikkan oleh Thailand dan Indonesia yang menerima bantuan IMF. Pihak kerajaan bertindak menginstitusikan gerak kerja menangani kesan krisis dan melaksanakan formula khusus bagi agenda pemulihan ekonomi dengan menubuhkan MTEN pada 7 Januari 1998 untuk menguruskan krisis ekonomi dan mengurangkan jurang antara sektor kerajaan dan swasta. Penginstitusian gerak kerja menangani krisis ekonomi membolehkan struktur kuasa dan juga pengarahan kepada semua sektor untuk diaplikasikan adalah satu langkah tepat kerana ia mendapat restu dan sokongan kukuh institusi Perdana Menteri dan Kerajaan Malaysia secara holistik. MTEN jelas berfungsi sebagai "kabinet profesional" berbanding fungsi Kabinet sedia ada yang dianggotai ahli politik. MTEN adalah "kabinet profesional" yang dianggotai pelbagai latar belakang kepakaran yang dipayungi oleh ahli politik yang jitu matlamatnya mahu membendung kesan negatif krisis ekonomi yang melanda ketika itu.

Langkah MTEN yang diperkenalkan oleh tindakan kepimpinan Tun Dr. Mahathir Mohamad dengan penghasilan satu kerangka tindakan di namakan sebagai Pelan Pemulihan Ekonomi Negara (PPEN) yang berorientasikan kepada usaha mengekalkan kestabilan kewangan, mengukuhkan asas ekonomi dan ekuiti di dapati berjaya dilaksanakan dengan berkesan. Hasil dari implementasi tersebut, ia berjaya mengeluarkan Malaysia dari krisis ekonomi tersebut dan pertumbuhan ekonomi negara pada tahun 1999 telah melonjak ke 6.1 peratus berbanding -7.4 peratus pada tahun 1998 (Wong Sulong, 2011). Duta dan Ketua Delegasi Kesatuan Eropah ke Malaysia, Vincent Pike telah mengiktiraf penyelesaian dan pendekatan yang dilaksanakan Malaysia ketika mengharungi krisis kewangan Asia pada tahun 1997/1998 (Che Wan, 2011). Malaysia berjaya mengharungi gugatan ekonomi dan juga berjaya mengekalkan kerajaan sedia ada semasa krisis ekonomi 1997/98 dan tidak berlaku regime change sepertimana berlaku ke atas negara-negara lain.

Tugas MTEN yang ditubuhkan pada era kepimpinan Tun Dr. Mahathir telah diguna pakai sebagai satu platform yang berperanan menyediakan pelan tindakan komprehensif bagi memulihkan semula daya ekonomi negara dari terus dilanda kegawatan. MTEN dilihat sebagai satu badan pelaksana, pemantau dan penilaian negara (Hasmiah, 2007: 214). Walaupun krisis ekonomi yang membadai negara pada 1997 telah berjaya dipulihkan, namun MTEN yang ditubuhkan pada masa gawat tahun 1997 berterusan fungsinya sepanjang pentadbiran Tun Dr. Mahathir sehingga 31 Oktober 2003. Menurut Hasmiah (2007), MTEN yang diwujudkan juga berperanan sebenarnya dalam melicinkan pengurusan sektor awam, proses birokrasi yang rumit dan berperingkat serta memakan masa panjang untuk kelulusan telah berjaya dipintasi dan dikurangkan. Ini sekali gus meningkatkan keberkesanan pengurusan dan pemaksaan tindakan rangsangan ekonomi bagi pemulihan semasa ekonomi dalam stres telah dapat dilakukan oleh pentadbiran Tun Dr. Mahathir. Harus disedari bahawa dalam usaha pemulihan ekonomi semasa gawat, proses birokrasi yang rumit dan memakan masa panjang serta tidak efisien akan menyebabkan pembangunan tersekat dan penjanaan pasaran akan tidak dapat segera diaktifkan. Untuk itu, dalam hal pembangunan negara, resepsi kejayaan Mahathiriskonomism juga dilihat atas sokongan penasihat yang komprehensif dan berkualiti.

Sebagai langkah bagi menjadikan aktiviti pemulihan ekonomi yang efektif dan efisien terutamanya dalam menjayakan pelaksanaan PPEN, pihak MTEN telah mengambil langkah seperti yang dinyatakan 
Hasmiah (2007) telah menjemput menteri dan ketua-ketua bagi kerajaan setiap negeri di Malaysia untuk menghadiri mesyuarat penghasilan rangka program bagi pemulihan ekonomi, khususnya yang membabitkan hal-hal berkaitan kuasa negeri seperti tanah, pertanian dan sumber asas. Melalui MTEN, koordinasi permuafakatan dan komitmen bersama secara berpusat telah dapat dibina dalam usaha menangani kesan kegawatan ekonomi dari terus membadai persekitaran geo-ekonomi, politik dan sosial negara. Ini menunjukkan bahawa model pengurusan ekonomi diwujudkan sebagai penyelarasan dan juga buah fikiran bersama secara kolektif adalah penting dan sihat dalam menghadapi gugatan akibat krisis ekonomi yang berlaku.

Menerusi MTEN, dalam usaha membendung kegawatan ekonomi semasa krisis ekonomi 1997, satu kerangka pelan tindakan telah dijanakan. PPEN telah dirangka dan diluluskan oleh Jemaah Menteri sebagai satu pelan dan kerangka tindakan pemulihan ekonomi (Hasmiah, 2007). Enam matlamat utama PPEN dirangka adalah bagi (1) menstabilkan nilai ringgit, (2) mengembalikan keyakinan pasaran, (3) mengekalkan kestabilan pasaran kewangan, (4) Memperkukuh asas-asas ekonomi, (5) merancakkan semula sektor yang terjejas, dan keenam, bagi meneruskan agenda ekuiti dan sosioekonomi.

Selain itu juga, dalam hal memastikan tahap kemiskinan negara terkawal, maka PPEN menerusi butiran yang terkandung dalam aspek kelima agendanya telah turut sama mencirikan beberapa langkah yang perlu diambil dalam memastikan struktur meneruskan agenda ekuiti dan sosioekonomi dapat dijayakan. Sembilan agenda di bawah matlamat tersebut ialah:

i. Menghapuskan kesulitan akibat kemiskinan

ii. Mengatasi isu-isu berkaitan pemilikan ekuiti bumiputera

iii. Memperluas peluang pekerjaan

iv. Memenuhi keperluan pelajaran tinggi yang pesat berkembang

v. Mengatasi masalah pengangguran siswazah

vi. Mengawal kemasukan pekerja asing

vii. Membolehkan perbadanan-perbadanan negeri menghadapi krisis

viii. Menyusun semula koperasi dan bank-bank

ix. Melindungi alam sekitar bagi pembangunan yang berkekalan

(Nor Aini, 2007:248)

Keberkesanan langkah dilaksanakan kerajaan menerusi MTEN jelas dapat dilihat secara jelas menerusi perkembangan kedudukan pasaran dan ekonomi Malaysia mula pulih dan pada tahun 2000, ekonomi negara mula mengalami pertumbuhan semula. Sejak krisis ekonomi yang melanda, proses pemulihan menampakkan kesan positif di mana paras pertumbuhan GDP telah mencatatkan purata 5.3 peratus dari 2001 hingga 2007. Walaupun ia lebih rendah berbanding kadar pertumbuhan GDP sebelum krisis ekonomi berlaku, iaitu pada kadar purata 8.1 peratus dari tempoh 1990 hingga 1997, namun, ekonomi Malaysia yang pulih dan berkembang telah memperlihatkan betapa proses pemulihan semula pasca krisis ekonomi 1997/98 berlaku dalam keadaan yang pantas dan cukup baik bagi mencapai tahap pertumbuhan yang tinggi (Mahani, 2009; Goh \& Michael, 2010).

Antara angkubah perubahan ekonomi negara dari kesan negatif krisis ekonomi ke arah pertumbuhan yang semakin pulih dilihat dari perkembangan pasaran positif di sektor penjualan kenderaan. Pada Oktober 1997, jualan kenderaan sebanyak 41,500 buah kepada hanya 12,000 unit pada Januari 1998 iaitu susutan sebanyak 71 peratus. Pasaran kenderaan dalam negara terus statik pada jumlah berkenaan sehingga September 1998. Peningkatan jualan mula berlaku pada Oktober 1998 dengan jumlah jualan sebanyak 14,000 unit, dan terus meningkat mencecah jumlah jualan sebanyak 20,000 unit pada Disember 1998 sehingga ia mencecah 25,000 unit setiap bulan pada penghujung 1999 (Mahani, 2002).

\section{Kesimpulan}

Kejayaan Dr. Mahathir membawa Malaysia memulihkan negara pasca krisis ekonomi 1997/98 adalah satu formula yang penting dalam mengubah landskap pengurusan ekonomi negara. Ia membuka 
perspektif baru dunia pengurusan politik-ekonomi antarabangsa dengan kejayaan Malaysia menangani krisis ekonomi tanpa perlu sandaran kebergantungan kuat terhadap institusi kewangan antarabangsa seperti IMF dan Bank Dunia. Ia membawa perbezaan, tetapi berjaya melakukan keajaiban. Elemen Mahathiriskonomism yang bercirikan Mahathirisasi dan gabungan kekuatan serta kewibawaan individu dan perundingan secara kolektif membawa impak formulasi yang berkesan kepada Malaysia era pemulihan kegawatan ekonomi 1997/98. Kini masih tidak terdapat dengan jelas pengkajian mengenai cara pengurusan Dr. Mahathir yang menjurus secara jitu peranan utama Dr. Mahathir itu sendiri sebagai tokoh yang memacukan pengurusan negara ke arah mencapai sasaran penyelesaian masalah krisis ekonomi yang berlaku. Ini perlukan kajian lanjutan berterusan oleh para akademia. Pandangan sering kali banyak tertumpu kepada dasar yang dilaksanakan, tanpa secara holistik menumpu sepenuhnya kepada aspek kepimpinan Dr. Mahathir secara khusus adalah perlu diperkemas. Hipotesis yang boleh dinyatakan hasil pengamatan artikel ini, Dr. Mahathir adalah pemimpin utama yang bertanggungjawab membawa kejayaan dengan memperkenalkan dan menggunakan dasar-dasar serta teori pengurusan dalam persekitaran politik ekonomi semasa bagi menyelamatkan Malaysia dari kesan tragis krisis ekonomi 1997/98. Kewujudan karya dan penyelidikan berkaitan Dr. Mahathir sebagai pencetus pengurusan krisis ekonomi 1997/98 dilihat signifikan untuk dijanakan. Mahathiriskonomism membawa prestij dan impak positif kepada rakyat dan negara dalam usaha pemulihan ekonomi negara akibat kegawatan ekonomi yang berlaku.

\section{Rujukan}

Anthony, D. S. (1996). The resurgence of nationalism? Myth and memory in the renewal of nations. British Journal of sociology, 47, 593.

Anthony, D. S. (1972). Theories of nationalism. Harper and Row, New York.

Anthony, D. S. (1995). Nation and nationalism in a global era, Polity Press, Cambridge.

Aaron, N. (2000). The Causes of the 1997-98 Asian Economic Crisis: A review of the academic literature and Comparison between Indonesia and South Korea, Department of Management Birkbeck, University of London.

Ahmad Atory Hussain. (2000). Analisis dasar awam: peranan kerajaan mengatasi masalah ekonomi dalam sistem pasaran bebas. Utusan Publications \& Distributors Sdn Bhd, Kuala Lumpur.

Arturo Bris, Yrjo Koskinen \& Vicente, P. (2004). Corporate Financial Policies and Performance Around Currency Crises. Journal of Business, 77(4), 749-795.

Athukorala, Prema-chandra (2008). The Malaysian capital controls: a success story?, Asian Economic Papers, The Earth Institute at Columbia University and The Massachussetts Institute of Technology.

Benedict, A. (1991). Imagined communities: Reflection on the origin and spread of nationalism, $2^{\text {nd }}$ Ed, Verso, London.

Caroline T. (1992), Third World Security, dalam Roger Carey dan Trevor C. Salmon (pnyt). (1992). International Security in the modern world. St Martin: New York. Hlm 98.

Chamhuri Siwar. (2007). Pengalaman Krisis Ekonomi di Negara-Negara Asia Timur, di dalam Nor Aini Haji Idris, Kegawatan Ekonomi Impak Terhadap Golongan Berpendapatan Rendah. Kuala Lumpur: Dewan Bahasa dan Pustaka.

Che Wan Badrul Alias (1997). Cara Malaysia tangani krisis 1997 diiktiraf, Berita Harian 27 Disember 2011.

Chris, B. (1992). International relations theory: New normative approaches, Harvester Wheatsheaf, London, 173-174.

Dhillon, K. S. (2009). Malaysian Foreign Policy in The Mahathir Era 1981-2003. Singapore: NUS Press.

Donald, M. S. (1998). National Security: Defence policy in a changed international order. St Martin's Press: New York.

M. Amstutz (1995). International Conflict And Cooperation: An Introduction To World Politics. Madison: Brown \& Benchmark.

Edward, N. M. (1995). Economic Determinants of Democracy. American Sociological Review, 60, 6, 966-982.

Francis, F. (1992). The end of history and the last man, Hamish Hamilton, London. 
Hanke, S. (2003). Suharto, Too, Was a Victim of Regime Change., The Australian (newspaper), 29 April, 2003.

Hans, M. (1948). Politics Among Nations, The Struggles For Power And Peace. New York: Alfred Knopf.

Harold, D. L. (1986). Politik, Siapa Mendapat Apa, Bila, Bagaimana. (Terj). Kuala Lumpur: Dewan Bahasa dan Pustaka.

Harris, S. (2000). Asian Multilateralism Institutions and Their Response to The Asian Economic Crisis: The Regional and Global Implications. Pacific Review, 13, 421-451.

Herman, E, S. (2003). The Threat of Globalization. Global Policy.

Ishak Yussof, Mohd Shukri Hajinoor \& Zulkifly Osman. (2009). Globalisation and Malaysia's economy di dalam Ishak Yussof, Malaysia's economy: past, present \& future, Malaysian Strategic Research Centre, Kuala Lumpur.

James, M. (1982). The Community Of States. London: George Allen \& Unwin.hlm72-83

Jim, G. (2001). Economic Crisis in Asia: The Case of Thailand. Economic Geography, 77(2), 122147.

Joseph, S. N. (2000). Understanding International Conflicts, An Introduction To Theory And History. New York : Longman.

Jurg, M. G. (1994). World views and theories of international relations, Macmillan, London, 1994.

Karen, M. (1979). Essentials Of International Relations. New York: W.W. Norton \& Company.hlm 77.

Kaur, H. (2003). IMF Praises Malaysia's Financial Management, New Straits Times, 3 Jun 2003.

Keating, P. (2000), 'Engagement: Astralia Faces The Asia-Pacific', Sydney: Macmillan,

Kenneth, W. (1979). Theory of International Politics. Massachusetts:Adison-Wesley.

K. J. Holsti (1991). Power, Capability And Influence In International Politics. Dalam Charles W. Kegley, Jr \& Eugenc R. Wittkof (Edt) The Global Agenda: Issue And Perspectives. London: McGraw Hill Inc. hlm. 13

K. Ramanathan (2000). Konsep Asas Politik. Pulau Pinang: Alms Digital Enterprise.

Khoo, B. T. (1995). Paradoxes of Mahathirism: an intellectual biography of Mahathir Mohamad. Oxforf University Press: Singapore.

Lyons, G. (2014). The consolations of economics: Good news in the wake of the financial crisis. London: Faber \& Faber.

Mahani Zainal Abidin, Malaysia's Economy: Crisis and Recovery in The Financial Crisis on Malaysia: The Economic and Political Consequences, Institute of Southeast Asian Studies, No 6, October 1999.

Mahathir. (1994). The Awakening. Uni-Strength Sdn. Bhd: Labuan. Hlm. 293.

Mahathir Mohamad (2003). Ucapan Dasar Presiden di Persidangan Agung UMNO ke 54: 'Mengenali Ancaman Terhadap Bangsa, Agama dan Negara', Berita Harian, 20 Jun 2003.

Mahathir Mohamad (1999). Case Study For A Country Under Economic Stress. Mainichi, Tokyo, August $2^{\text {nd }}, 1999$.

Mahathir Mohamad (9 Februari 1998). Ucapan di The Official Dinner In Honour Of His Excellency Rafic Hariri Prime Minister Of The Republic of Lebanon, di Seri Perdana, Kuala Lumpur dalam Collection of Mahathir's Speeches 1998. Jabatan Penerangan Malaysia, Kementerian Penerangan Malaysia, halaman 6-14.

Mahathir Mohamad (29 Januari 1999). Ucapan di The World Economic Forum Working Lunch, di Davos, Switzerland dalam Collection of Mahathir's Speeches 1999. Jabatan Penerangan Malaysia, Kementerian Penerangan Malaysia, halaman 9.

Mahathir Mohamad (28 November 1997). Ucapan di The Business Leaders Dialogue, di Tokyo, Jepun dalam Collection of Mahathir's Speeches 1997. Jabatan Penerangan Malaysia, Kementerian Penerangan Malaysia, halaman 463-480.

Mahathir Mohamad (1 September 1998). The Panel Discussion With Prime Minister, di Radio Televisyen Malaysia (RTM), Angkaspuri, Kuala Lumpur dalam Collection of Mahathir's Speeches 1998. Jabatan Penerangan Malaysia, Kementerian Penerangan Malaysia, halaman 185224.

Mahathir Mohamad (2 September 1998). Ucapan di The 12th Conference of The Heads of State or Heads of Government of The Non-Aligned Countries, Durban, South Africa dalam Collection of 
Mahathir's Speeches 1998. Jabatan Penerangan Malaysia, Kementerian Penerangan Malaysia, halaman 225-243.

Mahathir Mohamad (20 Jun 2003). Ucapan Dasar Presiden di Persidangan Agung UMNO ke 54: 'Mengenali Ancaman Terhadap Bangsa, Agama dan Negara', Berita Harian.

Md.Shukri Shuib (2007). Mahathiriskonomisme Mengekang Ancaman Kedaulatan Negara, Dewan Ekonomi, 49-51.

Md.Shukri Shuib. (2007). Mahathiriskonomism: Sorotan Krisis Ekonomi 1997/98. Kertas kerja dalam Seminar Internasional Memperkuat Landasan Hubungan Indonesia-Malaysia.Universitas Padjadjaran, Bandung, Indonesia, 15-16 Disember.

Md.Shukri Shuib, Mohamad Faisol Keling \& Mohd Na'eim Ajis. (2008). The Concept of Mahathiriskonomism: A Significant Model for Economic Turnmoil. Kertas kerja dalam Seminar International Conference on International Studies (ICIS) 2008. Institute Diplomacy and Foreign Relations (IDFR), Kuala Lumpur, 4-6 Disember.

Md. Shukri Shuib. (2008). Krisis ekonomi global bukan sebab kerajaan tak pandai urus ekonomi. Berita Harian. 11 Disember: 24.

Md. Shukri Shuib (2007). Kejayaan Tadbir Urus Ekonomi Malaysia: Model Inovasi Bertaraf Dunia. Dewan Ekonomi. July

Md. Shukri Shuib (2007). Sepuluh Tahun Kejayaan Pasca Kegawatan 1997. Dewan Ekonomi. Julai.

Md.Shukri Shuib (2007). 'Mahathiriskonomisme': mengekang ancaman kedaulatan negara melalui ekonomi. Dewan Ekonomi. Ogos

Mohammed Ayoob. (1995). Security in the Third World: the worm about to turn?, International Affairs, 60, 1.

Mohamad Faisol Keling et.al. (2006). Konsep asas hubungan antarabangsa dan pengajian strategi. Universiti Utara Malaysia: Sintok

Mohd Yusof, A. (1990). Continuity and change in Malaysia's foreign policy, 1981-1986 Phd Thesis. Tufts University: UMI.

Muhammad Azli Shukri (2007). Apakah Yang Sebenarnya Berlaku Pada Julai 1997. Dewan Ekonomi. Julai

Manuel, D. (1998). The Political and Social Implications of the Asian Crisis. Philippine Journal of Third World Studies, 13(4).

Mohd Hizam Hanafiah \& Zafir Mohd Makhbul (2008). Kesan Kegawatan Ekonomi ke atas Perniagaan Kecil: Penemuan dalam Perniagaan Francais, Jurnal Ekonomi Malaysia, 42, 45-63.

Nor Aini Haji Idris (2007). Kemiskinan dan Krisis Ekonomi: Analisis Terhadap Tindakan Pelan Pemulihan Ekonomi Negara (PPEN), di dalam Nor Aini Haji Idris, Kegawatan Ekonomi Impak Terhadap Golongan Berpendapatan Rendah. Kuala Lumpur: Dewan Bahasa dan Pustaka.

Nor Mohamed Yakcop (2009). Rahsia di sebalik krisis ekonomi, Berita Harian, 14 Mac 2009.

Rais Yatim. (2011). 1Malaysia Cabinet: Reflecting on cabinet governing. Mashi Publication Sdn. Bhd: Selangor.

Saadiah Mohamad. (2009). Bab 8 Malaysia's experience in monetary and exchange rate policy di dalam Ishak Yussof, Malaysia's economy: past, present \& future, Malaysian Strategic Research Centre, Kuala Lumpur.

Sachs, J. \& Radelet, S. (1998). The Onset of the East Asian Financial Crisis. NBER Working Paper No. 6680, Ogos 1998.

Sulaiman Mahbob. (2013). Good human capital leads to top economy. New Straits Times, 25 Julai 2013: 16.

Stiglitz, E. J. (2002), 'Globalization and its Discontents', Victoria, Australia: Penguin Books, 2002.

Surtahman Kastin Hasan \& Ishak Yussof. (2009). Bab 1 Economic development in Malaysia since independent di dalam Ishak Yussof, Malaysia's economy: past, present \& future, Malaysian Strategic Research Centre, Kuala Lumpur.

Schuman, M. (2009). The miracle: the epic story of Asia's quest for wealth. New York: Harper Business

Scot, B. et.al (2001). Theories Of International Relations. New York: Palgrave. hlm 70. lihat juga Martin Griffiths dan Terry Ocallaghan (2002). International Relations, The Key Concepts. London: Routledge.hlm 3

Sivamurugan Pandian. (2005). Legasi Mahathir. Utusan Publication \& Distributors Sdn Bhd: Kuala Lumpur. 
DOI: https://doi.org/10.47405/mjssh.v5i12.621

Sulaiman Mahbob. (2013). Good human capital leads to top economy. New Straits Times, 25 Julai 2013: 16

Timothy, L. et al. (1999). IMF- Supported programs in Indonesia, Korea and Thailand: A preliminary assessment. IMF: Washington.

Wong Sulong. (2011). Notes to the Prime Minister: The Untold Story of How Malaysia Beat the Currency Speculators. MPH Publishing: Kuala Lumpur.

Zakaria Haji Ahmad \& Baladas Ghoshal. (1999). The political future of ASEAN after the Asian crisis. International Affairs, 75(4), 759-778.

Zaherawati Zakaria, Zaliha Hj. Hussin, Nazni Noordin \& Mohd Zoolhilmie Mohamed Sawal (2010). Voice of Academia, 5(1), 79-96. 